\title{
Animals and Technoscientific Developments: Getting Out of Invisibility
}

\author{
Arianna Ferrari
}

Received: 2 February 2015 / Accepted: 3 February 2015

(C) Springer Science+Business Media Dordrecht 2015

\section{Animals and Technoscience}

The essays in the section "Animals in technoscientific developments" have been collected from the submissions to the 3rd European Conference of Critical Animal Studies that I organized in Karlsruhe on 28-30 November 2013. The aim of the conference was to stimulate critical scholars to engage on the multifaceted relationships between animals and technosciences, an underresearched topic.

Technoscience has become an important concept in the current debate on the epistemic and normative changes taking place in how scientific and technological research is currently being conducted. Although there are different modes of describing technoscience (and thus different interpretations of whether it is a "new" mode of knowledge production and when it started), generally speaking the term refers to a means of developing knowledge in which it is not possible to separate the scientific from the technological (cf., among others $[20,38])$. In contrast to the "traditional mode of doing science," in which scientific objects are relevant because there are facts about them, technoscience looks at the deep entanglements between theoretical representations (science) and technical interventions. Technoscience is,

\footnotetext{
A. Ferrari $(\bowtie)$

Institute of Technology Assessment and Systems Analysis

(ITAS), Karlsruhe Institute of Technology (KIT),

76021 Karlsruhe, Germany

e-mail: arianna.ferrari@kit.edu
}

therefore, interested in things as configurations of different interests [2].

The animal turn in humanities, realized through the establishment of human-animal studies (HAS) and critical animal studies (CAS) over the past two decades aims at integrating animals in scholarly and (social-) scientific inquiry and liberating them from the ontological status of objects $[14,52]$. Animals should be no longer perceived as mere metaphors or symbols but individuals in flesh and blood and involved in different mechanisms of knowledge productions and practices [41]. Critical perspectives on animals are shifting the focus of the inquiry from the insistence in looking for the capacities of animals to the complexity of interspecies relationships, critically challenging the idea of human domination and human exceptionalism (among others [63, 49, 52]).

Since the inquiry on technoscience shows the hybrid nature of knowledge and its producers, and thus fundamentally challenges differences between nature and culture, it works implicitly for the reconsideration of the idea of human exceptionalism, which is defined as "the premise that humanity alone is not a spatial and temporal web of interspecies dependencies" ([43]:11). As technoscience points out the interdependence and inseparability of science and technology and society, its inquiry cannot but embrace a rejection of the transcendental human subject who is external to socionatural entanglements and thus stresses the need to develop relational ontologies. The animal turn works toward revealing the profoundly interrelated nature of humans and animals. Therefore, the fact that technoscience indicates a different 
way of looking at the interrelations between knowledge, technological tools, and social meanings, it renders it more open to reconfiguring human-animal relationships capturing animal subjectivity. Of course the inquiry on technoscience, on the way in which it produces knowledge and conceptualizes things, should not be confused with technoscience itself. A deep tension emerges from the papers in this issue: Technosciences involving animals, such as genetic engineering, do not overcome human exceptionalism (cf. Weisberg's and Camezind's papers in this issue). Nevertheless a close look at the way in which technosciences operate can be of help in critically reflecting on the interconnectedness of the living and of human and nonhuman animals in particular.

The analysis of animals in technoscience represents an analysis of human-animal relationships which says something about our biography and our values, precisely because both humans and animals are subjects in these interrelations. Donna Haraway's reflections on the OncoMouse [28] has been considered as the first showing the entanglements between science, technology, and animals in a relational way. The OncoMouse is a product of the knowledge economy and viewed by the researchers as an entirely self-sufficient system: rather than extrapolating general biological facts in order to apply them to humans is no longer; according to Haraway, biotechnologists are producing cures for the diseases of these particular "animal models" (cf. [2]). Here, we have to remember the sentence of a former director of the National Cancer Institute Richard Klausner to the Los Angeles Times: "The history of cancer research has been a history of curing cancer in the mouse. We have cured mice of cancer for decadesand it simply didn't work in humans" [10]. How far Haraway's OncoMouse really goes in showing animals as subjects and not as symbols is a matter of controversy (cf. [61, 62]). However, Haraway's analysis is valuable inasmuch as it reveals a discrepancy between conceptualizations of animals in biotechnological research, motivated by tinkering and control, and the (more traditional) way in which the apparatus of animal experiments is justified in law and in society (through the argument of the applicability and relevance of the result for human beings). Furthermore, Haraway's description of "laboratory animals" as "workers," though disturbing (cf. [62]), points to their nature as individuals with agency and therefore contains the potential for leading to their consideration as subjects.

\section{The Invisibility of Animals in the Current Analysis of Science and Technology}

Despite this promising link between the regime of technoscience and the emergence of the animal turn in the humanities, the academic work has remained very scarce. In the most important anthologies on philosophy of technology, ethics of technology and STS, there is no in-depth analysis of the different ethical and social implications of the role of animals for science and technology (see, among others, [33, 39]; cf. [18]). This is the case, although animals are ubiquitously present in virtually all technoscientific fields. If animals are mentioned in inquiries on technoscience, they are often subsumed under more general concerns for the environment (cf. [27]), notwithstanding for example the accusation already made by [9] that the field of environmental sociology is dominated by anthropocentrism.

Almost every technoscientific innovation is tested on animals before being placed on the market. Although there is a long history of controversies over animal testing and although the use of the so-called genetically modified animal models poses interesting questions regarding knowledge production, animal experiments are not seen as an important topic for the inquiry on technoscience. In the vast majority of this literature animals are simply considered as part of the means of production or as "living laboratory equipment" (cf. [34, 35]) and not as subjects (with the notable exceptions of the works by [4] on the notion of performativity and by [30] with her contested definition of animals as "laborers"). Just very recently, it was proposed that the cloning of endangered animals be approached through the category of transposition, which "offers analytic purchase beyond the site of 'models' to include the social processes involved in making a full range of new kinds of mixtures through the life sciences and biomedicine" ([23]: 46).

In the field of the social studies of science, studies have been conducted over the practices of producing biomedical knowledge (for example, [12, 24, 42]) and on the importance of animals in the technoscientific development of the biomedical sciences and therapeutics across the past [7], but a specific focus on the deep meaning of technoscientific developments for animals themselves is lacking. Considerations of biopolitics, which have put the living body at the center of interest [45, 47], have been largely developed retaining their focus on the human, thus ignoring the current animal 
turn in humanities. Remarkable exceptions here are offered by the analysis of Franklin [22], who has suggested that the genealogy of the cloned sheep Dolly is increasingly our own (biologically, technologically, and culturally as well as socially), as well as by the analysis of the critical animal studies scholar Twine [56], who described the ontological implications of biotechnological practices for animals. The absence of common patterns in the implications of technoscience for humans and animals has recently been acknowledged by Rose [46], who has pointed out that the comprehensive perspective of engineering life represents a general tendency of the technologization of vitality, which characterizes the life sciences from genetic engineering to synthetic biology.

Animals are the targets of technological visions, as the debate over animal enhancement and animal disenhancement testifies, but this, again, appears to be only of marginal interest for scholars. In this respect, Nanoethics has been a pioneering journal in hosting various articles on this topic $([54,40]$; the special issues on animal disenhancement including [17, 26, 32, 31]). Visions of modifying animals or of creating new entities to respond to environmental challenges such as climate change, the example of Enviropigs and the in vitro meat show, are slowly gaining importance among scholars because they interestingly mix with strong narratives such as sustainability (cf. [51]).

Animals offer also inspiration for human-machine interfaces and robotics, they become objects for remote controlling and "models" for neuroscientific research, but almost any one of these uses deserves much critical analysis in the literature on technoscience. Animals are also absent in the reflection on the implications of food and agricultural biotechnology (cf. [55]), notwithstanding the fact that agriculture is a good example of the complex mix of the animal, the human, and the technological.

In a recent editorial for a special Section on Neuroethics and Animals in the Cambridge Quarterly of Healthcare Ethics [6], there is a cautious recognition of the enormous manipulative potential of neurotechnologies for animal minds. However, the necessity of broadening the "humanistic focus" of the neuroethics discourse is still being developed within a framework of human exceptionalism: the epistemic concerns regarding animal minds are interesting to the authors inasmuch as they open the door for an externalist account of cognitive functions (whereas the usual approach to human minds is internalist), but the view of the mind remains clearly humanistic, denying that animals have a sophisticated conscious mental life and that their behavior could be described as intentional and voluntary ([6] 124-125). The authors' preoccupations are still focused on the similarities and differences between "the" human and "the" animal.

For many scholars, it appears easier to conceive bred animals as "artifacts" or to engage in the discussion of the moral status of complex machines and technical systems rather than working on the different implications of a changed concept of subjectivity for nonhuman living beings (with some exceptions, such as [13, 25]). The lack of deep involvement in the debate on the relevance of sociocognitive abilities for the attribution of moral status (cf. [21]) and on the possibility of considering some animals even as moral agents (cf. [1, 48]) represents a serious deficit for discussions on the desirability of constructing artificial moral agents (e.g., [60]). Attempts to formulate a different concept of society that includes artifacts $[19,36]$ or to formulate nonhumanist or posthumanist ethics by enlarging the community of moral agents to include artifacts (cf. for example, [57, 58]) have been conducted in the majority of the cases without any deep connection to work in human-animal and critical animal studies (with some exceptions, such as [53]). This is, again, another important deficit, considering the potential of a new concept of agency liberated from anthropomorphic properties which are imbedded in posthumanist accounts and actor-network theory ([15]; cf. [44]).

Some promises seem to come from posthumanist work, which are characterized by a fundamental critique of modern rationality and thus of the conception of subjectivity (human subject) defined as conscience and will. Posthumanist theorists have been working on the elaboration of a posthumanist subject as a hybrid being (cf. $[29,30])$ or as a nonnaturalistic, vitalistic, and selforganizing entity capable of transcending boundaries (cf. [5]). Their definition of a subject is, therefore, clearly not confined to the mere human species, but extends beyond species boundaries. However, the implications for animals in technoscientific practice remain in many cases unclear, also due to the diffuse reluctance of posthumanist theories to take clear normative stances (cf. [50, 62]).

The invisibility of animals is maybe not surprising at all if we consider that the very definition of technology excludes any reference to the nonhuman living: the idea 
of an ontological difference between the human and the animal use of tools (which goes back to the Aristotelian thinking about techné (and understands only the human use as authentically purpose-oriented), is still predominant. This anthropocentric focus has recently been acknowledged by Vermaas et al. [59]: "A question that is more difficult to answer is the question of whether the objects that animals produce can be described as technical artefacts. You may perhaps be inclined to maintain that certain objects are technical artefacts like, for instance, the dams created by beavers or the twigs fashioned by apes to get ants out of anthills. Simultaneously, other products, such as cobwebs, might seem less likely candidates. Where will you draw the line?" ([59]: 20). The idea of human exceptionalism is also very well exemplified by the way in which animal life/animal behavior is scientifically studied. Even if it is recognized that certain species can transmit the use of tools to their descendants, they have developed sophisticated forms of communication and exhibit culture [3], in contemporary (cognitive) ethology, animality is reduced to behavior and behavior to causal mechanisms (cf. [37]). This approach reproduces the idea of human exceptionalism inasmuch as it reduces the notion of environment to an extremely poor naturalistic ecology suggesting that animals are organisms deterministically adapted to a set of objective conditions ([37]: 127) and belittling at the same time the presence of the humans who interact in different ways with animals. A critical stance toward the contemporary ethological paradigm is offered by the biconstructivist paradigm developed by Despret and Lestel, which fully assumes the phenomenological posture. In the biconstructivist paradigm, ethology can then be considered the science of the human interpretation of animal interpretation, taking "as axiomatic the subjectivity of animals and the situational emplacement of their human observers as living beings themselves" ([37]: 128). There will perhaps also be a space for truly engaging in questioning the rightness of an anthropocentric understanding of technology and technoscience.

\section{The Essays in This Special Issue}

The essays in this special issue investigate the complex interrelatedness of animals and technoscience from different angles. Colin Salter focuses on the uses of animals in the military-industrial complex, the interlinked structure of government, scientific institutions, and military agencies which use animals in a variety of ways, including genetic engineering and neuroscience. Salter points out that we need a profound analysis not only of the consequences of military developments on the suffering and killing of animals, but that we more importantly need to reflect on the deep anthropocentrism which embeds the military-industrial complex in the first place, in which we demand the sacrifice of animals for systems of suffering and death both for humans and for animals.

The most investigated technoscientific field is related to developments in molecular biology since they render it possible to shape animal bodies and identities, as already indicated in the previous paragraph, therefore it is not surprising that this is reflected in the these essays. Samuel Camenzind shows the insidiousness of the broadly used metaphor of cloning as a genetic copy in the debate around somatic cell nuclear transfer (SCNT): although this metaphor is often used to criticize cloning, depending on the way in which scholars appeal to the relationship between nature and culture, it can also be used to simply indicate general objectification tendencies in biomedical research or even to support cloning (through the argument that clones also exist in nature). For Camenzind, SCNT is better understood as a practice of splitting rather than of copying and it implies the objectification of animals.

The contribution by Zipporah Weisberg develops a fundamental critique of biotechnological modifications. For Weisberg, interventions on the genome of animals are forms of exploitation not only because they generate suffering, but because they accomplish an ontological collapse between the essence of animals as embodied subjects and the rationalizing and utilitarian logic of technosciences. Weisberg therefore sees no possibility of developing biotechnologies as endeavors which can liberate animal subjectivity. Her critique lies at the foundation and marks a categorical objection to the spirit of technoscience.

Anne Franciska Pusch's essay is dedicated to the exploration of fictional literature engaging with technoscience, focusing on the MaddAddam trilogy of Margarete Atwood, one of the most important fictional works on the genetic engineering of animals. The merits of Pusch's work are two: first, this essay demonstrates how fictional work can significantly overlap with real scientific results and thus be of value in reflecting on technoscience; second, it underlies the ability of Atwood to make it possible for the reader to critically 
engage with the results of science and technology, helping her to develop empathy and respect for animals. In this sense, literary work can challenge the task of other forms of analysis in truly develop a practical perspective.

Finally, the essay of Roberto Marchesini, who founded a center for posthumanist philosophy in Italy, represents a contribution to explaining how a posthumanist account can be seen as fertile ground for a mature reflection on technoscience. Marchesini's reflection is theoretical and aims at establishing the epistemic and ontological basis for rethinking about technoscientific development. Differently than other posthuman scholars, who in his opinion celebrate the power of humanity and thus rest on fundamental anthropocentric grounds, Marchesini shows the essential role of animals in shaping the identity of human beings (he speaks of an "animal epiphany"). He also does not refrain from taking position on the normative implications of this shift, clearly embracing an antispeciesist perspective (cf. [8]).

\section{Outlook}

Technoscience nowadays shapes our lives because, by largely defining what is possible, it constantly creates visions of good life. Rather than simply be the application of certain principles in order to realize certain things (object), technoscience involves the shaping of systems and relationships, offering a proper "mode of existence," and transforming how we live and who we are. Animals are not escaping this faith: they are there, at the forefront of many technological innovations; they are modified in their body, becoming material for different technologies; they suffer; they die; and they thus raise fundamental ethical and political questions. Technoscience creates modes of perceiving and conceptualizing animals which have to be critically scrutinized.

Provocatively, we can say that until now animals have not seemed entitled to enter the discourse on technology as subjects; if they are discussed, they are merely symbols, matters of comparisons or metaphors. The broad absence of considerations around animality in technoscience represents not only an analytical inaccuracy, but contributes to alimenting the idea of a profound and ontological difference between "the human being" and "the animal," an opposition which is at the origin of power mechanisms, and the affirmation of the absolute legitimacy of human domination and human exceptionalism. With their promotion of a different mode of looking at entanglements between subjects, knowledge, and technologies, the inquiry on technoscience could be an opportunity to accomplish a change in perspective into the analysis of scientific and technological development.

\section{References}

1. Bekoff M (2008) Wild justice: the moral lives of animals. University of Chicago Press, Chicago

2. Bensaude-Vincent B et al (2011) Matters of interest: the objects of research in science and technoscience. J Gen Philos Sci 42:365-383

3. Benz-Schwarzburg J (2012) Sozio-kognitive Fähigkeiten bei Tieren und ihre Relevanz für Tierethik und Tierschutz. Harald Fischer Verlag, Erlangen

4. Birke L et al (2004) Animal performances. An exploration of intersections between feminist science studies and studies of human/animal relationships. Fem Theory 5(2):167-183

5. Braidotti R (2013) The posthuman. Polity Press, CambridgeMalden

6. Buller et al (2014) Broadening the focus. Special section: neuroethics and animals, guest editorial. Camb Q Healthc Ethics 23:124-128

7. Bynum WF, Nutton V (eds) (1991) Essays in the history of therapeutics. Rodopi, Amsterdam

8. Caffo L, Marchesini R (2014) Così parlò il postumano. NovaLogos editrice, Aprilia

9. Catton W, Dunlap R (1978) Environmental sociology: a new paradigm. Am Sociol 13:41-49

10. Cimons M, et al (1998) Cancer drugs face long road from mice to men. Los Angeles Times, May 6, 1998, page A1

11. Clark JL (2014) Labourers or lab tools? Rethinking the role of lab animals in clinical trials. In: Taylor N, Twine R (eds) The rise of critical animal studies, from the margins to the center. London and New York, Routledge, pp 139-163

12. Clarke A, Fujimura JH (1992) The right tools for the job: at work in twentieth-century life sciences. Princeton University Press, Princeton

13. Coeckelbergh M (2012) Growing moral relations: critique of moral status ascription. New York, Palgrave Macmillan

14. DeMello M (2012) Animals and Society. An Introduction to Human-Animal Studies. New York, Columbia University Press

15. Drake P (2015) Marxism and the nonhuman turn: animating nonhumans, exploitation, and politics with ANT and animal studies, in rethinking Marxism: a journal of economics. Cult Soc 27(1):107-122

16. Dunlap RE, Catton WR (1979) Environmental sociology. Annu Rev Sociol 5:243-273

17. Ferrari A (2012) Animal disenhancement for animal welfare: the apparent philosophical conundrums and the real exploitation of animals. A response to Thompson and Palmer. Nanoethics 6/1:65-76 
18. Ferrari A (2013) Tier und Technik. In: Grunwald, A (ed) Handbuch Technikethik. Metzler, Stuttgart and Weimar, pp 203-207

19. Floridi L, Sanders JW (2004) On the morality of artificial agents. Mind Mach 14(3):349-379

20. Forman P (2007) The primacy of science in modernity, of technology in postmodernity, and of ideology in the history of technology. Hist Technol 23(1/2):1-13, 67-72

21. Francione G (2008) Animals as persons. Essays on the abolition of animal exploitation. Columbia University Press, New York

22. Franklin S (2007) Dolly mixtures: the remaking of genealogy. Durham and London, Duke University Press

23. Friese C, Clarke A (2012) Transposing bodies of knowledge and technique: animal models at work in reproductive sciences. Soc Stud Sci 42:31-52

24. Fujimura (1996) Crafting Science: A sociohistory of the quest for the genetics of cancer. Harvard University Press, Harvard

25. Gunkel DJ (2014) A vindication of the rights of machines. Philos Technol 27:113-132

26. Hadley J (2012) Confining 'disenhanced' animals. NanoEthics 6(1):41-46

27. Hanks C (ed) (2010) Technology and values. Essential Readings, Wiley-Blackwell, Malden/Oxford

28. Haraway D (1997) Modest_Witness@Second_Millenium. FemaleMan(C_Meets_OncoMouse ${ }^{\mathrm{TM}}$. Routledge, New York

29. Haraway D (2003) The companion species manifesto: Dogs, people, and significant otherness. Chicago, University of Chicago Press

30. Haraway D (2008) When species meet. Minneapolis and London, University of Minnesota Press

31. Henschke A (2012) Making sense of animal disenhancement. NanoEthics 6(1):55-64

32. Hongladarom S (2012) The disenhancement problem in agriculture: a reply to Thompson. NanoEthics 6(1):47-54

33. Kaplan, DM (ed) (2004) Readings in the Philosophy of Technology. Rowman \& Littlefield Press, Lanham

34. Knorr-Cetina K (1999) Epistemic cultures: how the sciences make knowledge. Harvard University Press, Cambridge MA

35. Kohler RE (1994) Lords of the fly: Drosophila genetics and experimental life. Chicago University Press, Chicago and London

36. Latour B (2005) Reassembling the social. An introduction to Actor-Network-Theory, Oxford University Press, Oxford

37. Lestel D et al (2014) The phenomenology of animal life. Environ Hum 5:125-148

38. Nordmann A (2011) The age of technoscience, in Nordmann A, Radder H, Schiemann G (eds) Science transformed? Debating claims of an Epochal break, University of Pittsburgh Press, Pittsburgh 19-30

39. Olsen, JKB et al (2009) Companion to the philosophy of technology. Blackwell Publishing

40. Palmer C (2011) Animal disenhancement and the non-identity problem: a response to Thompson. Nanoethics 5:43-48

41. Pedersen H, Stanescu V (2014) Future directions of critical animal studies. In Taylor N, Twine R (eds) The rise of critical animal studies, from the margins to the center. London and New York, Routledge, pp 262-275
42. Pickering A (1992) Science as practice and culture. The University Of Chicago Press, Chicago

43. Pickering A (2008) Against human exceptionalism. https:// ore.exeter.ac.uk/repository/bitstream/handle/10036/18873/ XTRwrkshp-250108.pdf?sequence $=1$

44. Roelvink G (2013) Rethinking species-being in the Anthropocene. Rethink Marx 25(1):52-69

45. Rose N (2006) The politics of life itself: biomedicine, power, and subjectivity in the twenty-first century. Princeton University Press, Oxford

46. Rose N (2012) The human sciences in a biological age, ICS Occas Pap. Series Volume 3, Number 1

47. Rose N (2006) The politics of life itself: biomedicine, power, and subjectivity in the twenty-first century. Princeton University Press, Princeton

48. Rowlands M (2012) Can animals be moral? Oxford University Press, Oxford

49. Sorenson J (ed) (2014) Critical animal studies. Thinking the Unthinkable. Canadian Scholars' Press Inc., Toronto

50. Steiner G (2013) Animals and the limits of postmodernism. Columbia University Press, New York

51. Stephens N (2013) Growing meat in laboratories: the promise, ontology, and ethical boundary-work of using muscle cells to make food. Configurations 21(2):167

52. Taylor N, Twine R (eds) (2014) The rise of critical animal studies. From the margins to the center, Routledge New York

53. Teubner G (2006) Rights of non-humans? electronic agents and animals as new actors in politics and law. J Law Soc 4(33): 497-521

54. Thompson P (2008) The opposite of enhancement: nanotechnology and the blind chicken problem. Nanoethics 2(3):305331

55. Thompson PB (1994) The spirit of the soil, Routledge, New York

56. Twine R (2010) Animals as biotechnology: ethics, sustainability and critical animal studies. Earthscan, London and Washington

57. Verbeek PP (2011) Moralizing technology: understanding and designing the morality of things. University of Chicago Press, Chicago

58. Verbeek P-P (2008) Morality in design: design ethics and the morality of technological artifacts. In: Vermaas P et al (eds) Philosophy and Design. Springer, Berlin, pp 91-103

59. Vermaas P et al (2011) A philosophy of technology. From technical artefacts to sociotechnical systems. Morgan \& Claypool, San Rafael

60. Wallach W, Allen C (2009) Moral machines. Teaching robots right from wrong. Oxford University Press, Oxford

61. Weisberg Z (2009) The broken promises of monsters: Haraway, animals and the humanist legacy. J Crit Anim Stud II(VII):22-62

62. Weisberg Z (2014) The trouble with posthumanism: bacteria are people too. In: Sorenson J (ed) Critical Animal Studies. Thinking the Unthinkable. Canadian Scholars' Press Inc, Toronto, pp 93-116

63. Wolfe C (2010) What is posthumanism? University of Minnesota Press, Minneapolis and London 